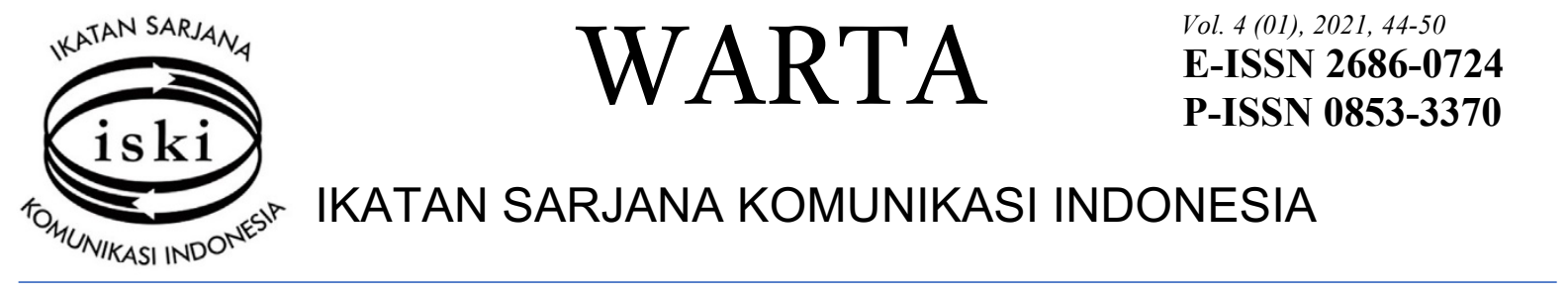

\title{
Pengaruh Brand Reputation dan Brand Experience terhadap Trust in a Brand serta Pengaruhnya pada Loyalitas Pelanggan
}

\author{
http://dx.doi.org/10.25008/wartaiski.v4i1.81
}

\author{
Alyedia Mei $^{1^{*}}$, Nindita Kartika Rahayu ${ }^{2}$, Rajab Ritonga ${ }^{3}$ \\ 1,2,3 Institut Komunikasi dan Bisnis LSPR \\ J1. KH Mas Mansyur Kav. 35, Jakarta 10220, Indonesia \\ *e-mail korespondensi: 19210320046@1spr.edu
}

Submitted: 11/03/2021, Revised: 30/05/2021, Accepted: 19/06/2021

Accredited by Kemristekdikti No. 30/E/KPT/2019

\begin{abstract}
iPhone is one of the products released by Apple which is one of the mobile phone brands favored by the public so that people are willing to buy this product even though the price is quite high. Advanced features that are always being upgraded, the connection speed on the iPhone makes people wait and buy the latest series from the iPhone. In addition, the use of the iPhone is not only a communication tool, the iPhone is also part of the lifestyle of today's society, consumers will buy products that provide an interesting experience for them, so that it will encourage them to repurchase the product. iPhone is in great demand by users, this makes the iPhone brand reputation very good. This study aims to describe the effect of brand reputation and brand experience on trust in a brand and their effect on customer loyalty iPhone X. This type of research is quantitative, the data is obtained by distributing questionnaires to 50 people with high school to master education levels who use the iPhone X.
\end{abstract}

Keywords: Brand reputation; brand experience; trust in a brand; customer loyalty; iPhoneX

\begin{abstract}
Abstrak
iPhone merupakan salah satu produk yang dikeluarkan Apple yang menjadi salah satu merek handphone yang digemari oleh masyarakat sehingga masyarakat rela membeli produk ini walau dengan harga yang cukup tinggi. Fitur-fitur canggih yang selalu di upgrade, kecepatan koneksi pada iPhone membuat masyarakat menunggu dan membeli seri terbaru dari iPhone. Di samping itu, penggunaan iPhone tidak hanya untuk alat komunikasi semata, iPhone juga merupakan bagian dari lifestyle masyarakat saat ini. Konsumen akan membeli produk yang memberikan pengalaman menarik bagi mereka, sehingga hal itu akan mendorong mereka untuk melakukan pembelian ulang terhadap produk tersebut. iPhone sangat diminati penggunanya, hal ini membuat reputasi merek iPhone sangat baik. Penelitian ini bertujuan untuk mendeskripsikan pengaruh brand reputation dan brand experience terhadap trust in a brand serta pengaruhnya pada loyalitas pelanggan iPhone X. Jenis penelitian ini kuantitatif, data diperoleh dengan penyebaran angket kepada 50 orang dengan jenjang pendidikan SMA hingga S2 yang menggunakan iPhone $\mathrm{X}$.
\end{abstract}

Kata Kunci: Brand experience; brand reputation; kepercayaan konsumen; kesetiaaan konsumen; iPhone

\section{PENDAHULUAN}

Produk teknologi informasi, iphone menjadi salah satu merek smartphone yang mempunyai reputasi tinggi di dunia teknologi komunikasi. iPhone merupakan produk yang dirancang Apple dengan menggunakan sistem operasi IOS pada perangkatnya, dan perangkat ini tidak mudah terkena virus. iPhone selalu dikaitkan dengan pemilik berpenghasilan tinggi, dengan segmentasi pasar kelas 
menengah ke atas, sehingga iPhone memiliki pengguna yang stabil. Ketertarikan pada merek iPhone menjadi sebuah fenomena tersendiri khususnya di kalangan masyarakat Indonesia. Pencinta merek iPhone menjadi semakin kuat seiring dengan semakin meluasnya pengetahuan dan kesadaran masyarakat atas kebutuhan alat komunikasi untuk mengakses internet.

Menurut Lau dan Lee (1999) reputasi sebuah merek merupakan opini dari pihak lain bahwa merek tersebut baik dan dapat diandalkan. Jika seseorang mendapati orang lain yang berpandangan bahwa suatu merek tersebut baik, maka konsumen akan percaya dan membelinya. Pada peluncuran produk iPhone terbaru, Phone X pada 3 November 2017 di beberapa negara, masyarakat rela antri dan berusaha mendapatan produk iPhone terbaru. Bahkan masyarakat tidak sungkan membeli dengan sistem PreOrder ataupun secara khusus pergi ke luar negeri untuk membeli iPhone X.

Perusahaan Apple mengeluarkan produk iPhone terbaru, iPhone X pada 3 November 2017 namun produk itu dilabeli sebagai salah satu produk gagal terbesar dan terburuk sepanjang 2017. Banyak rumor menyebutkan, iPhone X memiliki baterai yang boros dalam pemakaian. Baterai memengaruhi kinerja ponsel dan layar iPhone $\mathrm{X}$ tidak bereaksi ketika ada panggilan masuk, sehingga mereka tidak bisa menjawab telepon dengan menekan tombol virtual yang seharusnya muncul di layar.

Namun, di tengah rumor miring yang beredar, iPhone $\mathrm{X}$ tetap diminati oleh para pelanggan. Dari fenomena ini, penelitian ini ingin melihat apakah iPhone mampu mempertahankan reputasi baiknya di mata pelanggan. Penelitian ini dilakukan untuk mengkaji bagaimana pengaruh brand reputation dan brand experience terhadap trust in a brand serta pengaruhnya pada loyalitas pelanggan pengguna iPhone X.

\section{KERANGKA TEORI}

Komunikasi merupakan sebuah proses penyampaian isi dari pernyataan komunikator kepada komunikan dengan tujuan untuk mempengaruhi orang lain agar motif komunikasi dapat tercapai (Hoeta Soehoet, 2002). Perusahaan Apple Inc., sebagai komunikator menyampaikan isi pernyataan yaitu melalui peluncuran produk terbaru yang dikeluarkan Apple Inc., yaitu Iphone X agar masyarakat atau komunikan dapat mengetahui dan tertarik membeli produk tersebut.

Menurut Hoeta Soehoet (2002), proses komunikasi terjadi jika tersedia paling sedikit tiga unsur, yaitu komunikator, isi pernyataan dan komunikan. Berdasarkan penjelasan di atas proses komunikasi pada penelitian ini melibatkan public relations melalui kegiatan marketing public relations sebagai komunikator yang menyampaikan isi pernyataan peluncuran iPhone X. Komunikannya adalah pengguna iPhone.

Public Relations sejatinya berbicara mengenai reputasi, yakni hasil dari apa yang dilakukan, dan apa yang orang lain katakan tentang Anda. Praktik PR adalah disiplin ilmu yang bertugas menjaga reputasi, dengan tujuan mendapatkan pemahaman, dukungan, serta memengaruhi opini dan perilaku. Kegiatan ini merupakan usaha yang terencana serta berkesinambungan untuk membangun dan mempertahankan niat baik ataupun saling pengertian antara suatu organisasi dengan publiknya.

Public Relations memegang peranan penting dalam menjalin hubungan antara organisasi dengan publiknya agar publik dapat mendukung fungsi organisasi dan meminimalisir isu negatif yang beredar tentang perusahaan (Keith, 2014). Public relations diperluas dengan Marketing Public Relations yang secara khusus mendukung aktivitas penjualan mencapai target serta sasaran, melalui upaya memuaskan pelanggan dan mempertahankan agar pelanggan loyal terhadap suatu merek. Secara singkat, Marketing Public Relations merupakan suatu kegiatan terencana Public Relations untuk menanamkan kepercayaan pelanggan terhadap produk yang dihasilkan.

Suatu merek yang beredar di pasaran dapat dinilai dari banyak sisi. Salah satu yang menjadi penilaian publik terhadap suatu merek adalah brand reputation, trust in a brand dan loyalitas pelanggan. Menurut Lau dan Lee (1999), reputasi merek adalah opini orang lain bahwa merek tersebut bagus dan dapat dipercaya. Reputasi merek dapat dikembangkan melalui media periklanan dan publik relations. Reputasi merek juga dapat dipengaruhi dari kualitas dan kinerja merek. Secara singkat, Brand Reputation ditentukan oleh pelanggan, karena dibentuk oleh opini pelanggan. Public Relations mempunyai tugas untuk meyakinkan pelanggan bahwa suatu merek berkualitas dan dapat dipercaya.

Menurut Kotler (2000) indikator brand reputation ada tiga yaitu: (1) dikenal luas, (2) dapat dipercaya dan (3) nama baik. Menurut Gobe Marc (2003) pengalaman merek adalah interaksi mental langsung dengan merek. Merek dapat meningkatkan dan mengekspresikan karakter kuat emosional 
secara positif dengan menawarkan produk luar biasa yang bisa menjadi pengalaman merek tak terlupakan.

Terdapat empat dimensi yang digunakan untuk mengukur brand experience: (1) Sensory, menciptakan pengalaman melalui penglihatan, suara, sentuhan, bau, dan rasa; (2) Affection, pendekatan perasaan dengan memperngaruhi suasana hati, perasaan, emosi; (3) Behavior, menciptakan pengalaman secara fisik, pola perilaku, gaya hidup; (4) Intellectual, menciptakan pengalaman yang mendorong konsumen terlibat dalam pemikiran seksama mengenai keberadaan suatu merek (Brakusetal, 2009).

Kepercayaan pada merek (trust in a brand) adalah kesediaan atau kemauan konsumen untuk mempercayai atau mengandalkan merek dengan segala resikonya karena ada harapan bahwa merek bersangkutan akan memberikan hasil positif bagi konsumen Tjiptono, 2008). Menurut Lau dan Lee (1999), Trust in a Brand memiliki tiga dimensi yaitu:

(1) Brand Characteristic, berkaitan dengan kepercayaan konsumen terhadap suatu merek yang dinilai berdasarkan indicator yaikni (a) merek dengan reputasi tinggi, yaitu merek dengan kualitas yang baik dan mampu bersaing dengan merek lain; (b) pengetahuan publik tentang merek, yaitu suatu tingkat pengetahuan masyarakat terhadap suatu merek; (c) berita positif, yaitu tingkat pengetahuan konsumen mengenai merek yang telah digunakan; (d) pengetahuan konsumen tentang merek, yaitu tingkat pengetahuan konsumen tentang merek yang digunakan; (e) merek yang konsisten dengan kualitasnya, yaitu tingkat konsistensi suatu merek dengan menjaga kualitas yang sesuai dengan keinginan masyarakat; (f) harapan konsumen terhadap merek, yaitu suatu keinginan konsumen terhadap apa yang dilakukan perusahaan pada produk yang dipasarkannya; (g) berbeda dengan merek yang lain, yaitu perbandingan dengan merek lain dengan bidang yang sama yang memiliki kekuatan merek yang berbeda;

(2) Company Characteristic, yang ada dibalik merek akan berpengaruh terhadap loyalitas merek. Karakteristik ini meliputi reputasi suatu perusahaan serta integritas perusahaan dibalik merek tersebut. Company characteristic dinilai berdasarkan: (a) kepercayaan terhadap perusahaan, yaitu suatu tingkat kepercayaan konsumen ataupun pelanggan terhadap perusahaan; (b) keyakinan pelanggan terhadap produk perusahaan, merupakan wujud dari hasil suatu komitmen perusahaan untuk melayani konsumennya dengan baik;

(3) Consumer - Brand Characteristic, merupakan totalitas pemikiran dan perasaan individu dengan acuan dirinya sebagai objek sehingga sering kali dalam konteks pemasaran dianalogikan merek sama dengan orang. Dimensi ini dinilai berdasarkan: (a) ada kesamaan merek dengan emosi pelanggan, yaitu antara perusahaan dengan konsumen memiliki keinginan dan tujuan yang sama; (b) merupakan merek favorit, yaitu persepsi konsumen akan suatu merek yang diinginkan tentunya dengan kualitas yang baik; (c) merek yang sesuai dengan kepribadian pelanggan, merupakan suatu persepsi konsumen akan merek suatu produk yang digunakan.

Loyalitas pelanggan menjadi indikator penilaian suatu merek dipasaran karena dengan adanya loyalitas menunjukan ada pasar di sana. Menurut Hurriyati (2010,) loyalitas adalah komitmen yang kuat dari pelanggan untuk berlangganan kembali atau melakukan pembelian ulang produk/jasa terpilih secara konsisten di masa yang akan datang, meskipun pengaruh situasi dan usaha-usaha pemasaran mempunyai potensi untuk menyebabkan perubahan perilaku.

Ada empat dimensi yang dilihat dalam menilai loyalitas pelanggan, yakni (1) Word of Mouth Communication, dimensi ini menilai bagaimana seseorang merekomendasikan, memberitahukan keunggulan merek tersebut dan mengajak orang lain menggunakan brand tersebut; (2) Purchase Intentions, bagaimana seseorang tetap menjadi pelanggan, mengurangi penggunaan merek lain, bangga menjadi pengguna suatu brand dan memiliki intensitas kunjungan atau pembelian yang tinggi terhadap merek tersebut; (3) Price Sensivity yaitu kemungkinan konsumen berpindah merek ketika ada perubahan harga, memilih merek dengan harga yang lebih menarik, kenaikan harga dan diskon pada merek tersebut; (4) Complaining Behavior, menilai bagaimana konsumen mengadukan masalah pelayanan, komentar negatif, turunnya intensitas kunjungan konsumen bahkan perpindahan menjadi pelanggan merek lain.

Hubungan Brand Reputation terhadap Trust in a Brand

Menurut Creed\& Miles (1996), reputasi sebuah merek merujuk pada opini orang lain bahwa merek tersebut baik dan bisa diandalkan. Bila konsumen merasa orang lain memiliki opini bahwa merek 
tersebut bagus (ia memiliki reputasi baik) konsumen akan cukup mempercayai merek tersebut hingga membelinya. Artinya, brand reputation memiliki pengaruh terhadap trust in brand.

Menurut penelitian Yosafar Tanjung Hadianto (2011) brand reputation menjadi sebuah issue dari sebuah sikap dan kepercayaan kepada penghargaan, image, kepuasan serta loyalitas pelanggan (Andreassen, 1994). Pernyataan tersebut menunjukan bahwa brand reputation memiliki pengaruh terhadap loyalitas pelanggan. Penelitian Ken Sudarti dan Illa Fitria Andika Putri (2013) memperkuatnya yakni ada pengaruh positif reputasi merek terhadap loyalitas pelanggan.

Hubungan Brand Experience dengan Trust in a Brand menurut Koufaris dan Hampton-Sosa (2002), pengalaman mampu menimbulkan kepercayan konsumen dan itu dapat diciptakan oleh penjual atau perusahaan. Namun untuk menciptakan pengalaman yang mampu menimbulkan kepercayaan tersebut, penjual atau perusahaan harus memiliki beberapa karakteristik seperti menjadi perusahaan yang memang ahli di bidangnya dan keinginan untuk selalu mendampingi konsumen pada kondisi apapun.

Atas dasar pernyataan tersebut dapat disimpulkan bahwa brand experience memiliki pengaruh terhadap trust in a brand. Menurut penelitian Agata Rahmi Pertiwi, Achmad Helmy Djawahir dan Andarwati (2017) ada pengaruh positif brand experience terhadap trust in a brand. Menurut Zarantenello dan Schmitt (2000); Ha dan Perks (2005), pengalaman merek menjadi salah satu potensi dorongan dalam menciptakan perilaku loyalitas merek atau loyalitas konsumen terhadap suatu merek.

Selain itu, pengalaman merek juga dapat memberikan pengaruh pada kepercayaan merek dan kepuasan merek. Terlebih, pengalaman merek dapat memberikan pengaruh positif pada kepuasan konsumen dan loyalitas merek sama seperti kepercayaan merek. Kerangka pemikiran di atas menjelaskan bahwa brand experience memiliki pengaruh terhadap loyalitas pelanggan.

Penelitian Alex Fahrur Riza dan Dwi Marlina Wijayanti menunjukkan brand experience berpengaruh terhadap kepuasan pelanggan, begitu juga penelitian Muhamad Bhimanto, brand experience berpengaruh terhadap Brand Loyalty. Hubungan Trust in a Brand dengan Loyalitas Pelanggan, menurut Brown (1952); Tucker (1964) dalam Lau dan Lee (1999), loyalitas merek dapat dikonseptulisasikan sebagai pola perilaku pembelian aktual terhadap suatu merek, atau minat berperilaku terhadap merek.

Kerangka pemikiran di atas menjelaskan bahwa Trust in a Brand memiliki pengaruh terhadap loyalitas pelanggan. Hal itu juga diperkuat pada penelitian Andri Helmi Munawar yang menunjukkan Brand Trust berpengaruh terhadap CustomerLoyalty.

\section{METODE PENELITIAN}

Penelitian ini menggunakan paradigma positivistik. Pemilihan paradigman disesuaikan dengan permasalahan penelitian yang menggunakan pendekatan kuantitatif dan gejala-gejala yang bersifat sebab akibat, yaitu pengaruh Brand Reputation dan Brand Experience terhadap Trust in a Brand serta pengaruhnya pada Loyalitas Pelanggan.

Pendekatan penelitian ini menggunakan kuantitatif. Menurut Efferin (2008), penelitian kuantitatif merupakan penelitian yang menekankan pada pengujian teori-teori dan atau hipotesis-hipotesis melalui pengukuran variabel-variabel penelitian dalam angka (quantitative) dan melakukan analisis data dengan prosedur statistik dan atau permodelan matematis.

Metode yang digunakan pada penelitian ini adalah survei. Menurut Kriyantono (2008) metode survei adalah metode riset dengan menggunakan kuesioner sebagai instrument pengumpulan data. Tujuannya untuk memperoleh informasi tentang sejumlah responden yang dianggap mewakili populasi tertentu.

Populasi dalam penelitian ini adalah pengguna iPhone X baik pria maupun wanita. Menurut Silalahi (2015), terdapat skala yang dapat digunakan dalam penelitian sosial kuantitatif. Skala yang digunakan dalam penelitian ini adalah Skala Likert yaitu skala yang digunakan untuk mengukur sikap, pendapat, atau persepsi seseorang tentang dirinya atau sekelompok orang berhubungan dengan suatu hal.

\section{HASIL PENELITIAN}

Karakteristik 50 responden yang diteliti berdasarkan jenis kelamin, pria memiliki frekuensi 23 orang dengan presentasi $46 \%$ dan wanita memiliki frekuensi 27 orang dengan presentasi $54 \%$. 
Berdasarkan pendidikan terakhir, pendidikan SMA/sederajat sebanyak 7 orang dengan presentasi 14\%, S1 sebanyak 35 dengan presentasi $70 \%$, dan S2/S3 sebanyak 8 orang dengan presentasi $16 \%$.

Sebanyak 17 orang dengan presentasi 34\% berusia usia 35-43 tahun. Sebanyak 20 orang dengan presentasi $40 \%$, dan usia 44-52 tahun sebanyak 6 orang dengan presentasi $12 \%$. Berdasarkan pekerjaan, mahasiswa sebanyak 3 orang dengan presentasi $6 \%$, pegawai negeri sipil sebanyak 6 orang dengan presentasi sebanyak $12 \%$, karyawan swasta sebanyak 27 orang dengan presentasi $54 \%$, dan wiraswasta sebanyak 14 orang dengan presentasi $28 \%$.

Berdasarkan pengeluaran per bulan, responden dengan pengeluaran $\mathrm{Rp} 3.000 .0000-\mathrm{Rp} 4.500 .000$ sebanyak 5 orang dengan presentasi $10 \%, \mathrm{Rp} 4.600 .000$ - Rp 6.100 .000 sebanyak 6 orang dengan presentasi $12 \%$, Rp 6.200 .000 - Rp 7.700 .000 sebanyak 18 orang dengan presentasi $36 \%$, dan > Rp 7.800 .000 sebanyak 21 orang dengan presentasi $42 \%$.

Proses reduksi pernyataan pada analisis faktor Brand Reputation menghasilkan angka KMO Measure of Sampling Adequancy nama baik adalah sebesar 0,684 dengan signifikasi 0,00 lebih kecil dari 0,05 dan kemudahan diingat 0.682 signifikasi 0,00 lebih kecil dari 0,05 . Proses reduksi analisis faktor selanjutnya dari 6 pernyataan kedua indikator atau ke variabel Brand Reputation menghasilkan nilai KMO 0,500 dengan signifikansi 0,000. Anti-image Correlation menunjukkan BREPA 0.500 dan BREPB 0.500 .

Component Matrix menunjukkan nilai keenam item di atas 0,5. Proses reduksi analisis faktor selanjutnya dari enam pernyataan kedua indikator menghasilkan nilai. Component Matrix 0.928. Proses reduksi pernyataan pada analisis faktor Brand Experience menghasilkan KMO Measure of Sampling Adequancy 15 item menunjukkan angka diatas 0,500 dengan signifikasi 0,000 lebih kecildari 0,05, sehingga faktor hasil analisis data dapat dianalisis lebih lanjut.

Proses reduksi analisis faktor selanjutnya dari 15 pernyataan keenam indikator menghasilkan nilai KMO 0,735 dengan signifikansi 0,000 lebih kecil dari 0,05. Angka table Anti-image Correlation pada ke 15 item menunjukan angka diatas 0.5. Proses reduksi analisis factor selanjutnya dari 6 indikator keempat dimensi menghasilkan nilaiAnti-image Correlation BREXA 0.729, BREXB 0.734, BREXC 0.695, BREXD 0.815.

Pada tabel Component Matrix menunjukkan nilai keenam item di atas 0,5. Proses reduksi analisis faktor selanjutnya dari enam indicator ke empat dimensi menghasilkan nilai Component Matrix BREXA 0.879, BREXB 0.879, BREXC 0.911, BREXD 0.776. Proses reduksi pernyataan pada analisis factor Trust in a Brand menghasilkan angka KMO Measure of Sampling Adequancy 27 item menunjukkan angka di atas 0,500 dengan signifikasi 0,000 lebih kecil dari 0.05, sehingga faktor hasil analisis data dapat dianalisis lebih lanjut.

Proses reduksi analisis factor selanjutnya dari 27 pernyataan ke-11 indikator menghasilkan nilai KMO 0,616 dengan signifikansi 0,000 lebih kecil dari 0,05. Angka table Anti-image Correlation pada ke 27 item menunjukan angka di atas 0.5 . Proses reduksi analisis facto rselanjutnya dari 11 indikator ketiga dimensi menghasilkan nilai Anti-image Correlation 0.500. Pada tabel Component Matrix menunjukkan nilai keenam item di atas 0,5 . Proses reduksi analisis factor selanjutnya dari enam pernyataan keempat dimensi menghasilkan nilai Component Matrix TIABA 0.874, TIABB 0.725, TIABC 0.918.

Berdasarkan KMO dan Barlett Test pada analisis factor Brand Experience, angka KMO Measure of Sampling Adequancy 27 item menunjukkan angka di atas 0,500 dengan signifikasi 0,000 lebih kecil dari 0,05 , sehingga faktor hasil analisis data dapat dianalisis lebih lanjut. Proses reduksi analisis faktor selanjutnya dari 27 pernyataan ke 11 indikator menghasilkan nilai KMO 0,815 dengan signifikansi 0,000 lebih kecil dari 0,05. Angka tabel Anti-image Correlation pada ke 27 item (tabel) menunjukan angka di atas 0.5 .

Proses reduksi analisis factor selanjutnya dari 11 indikator keempat dimensi menghasilkan nilai Anti-image Correlation LOPELA 0.923, LOPELB 0.910, LOPELC 0.749, LOPELD 0.741. Pada tabel Component Matrix menunjukkan nilai ke 27 item di atas 0,5. Proses reduksi analisis faktor selanjutnya dari 11 indikator keempat dimensi menghasilkan nilai Component Matrix LOPELA 0.880, LOPELB 0.918, LOPELC 0.957, LOPELD 0.957.

Berdasarkan hasil output regresi linear berganda, yaitu Brand Reputation dan Brand Experience, pada tabel summary dapat dikatakan koefisien (R) sebesar 0,845 yang menjelaskan bahwa variable Brand Reputation dan Brand Experience berpengaruh terhadap Trust in a Brand sebesar 84,5\%. R square (R2) disebut koefisien determasi. Dari tabel dapat diketahui bahwa nilai R2 sebesar 0,714 
$(71,4 \%)$ dan sig sebesar 0,000 . Artinya $71,4 \%$ variasi yang terjadi terhadap tinggi rendahnya Trust in a Brand disebabkan variasi Brand Reputation dan Brand Experience.

Berdasarkan hasil pengolahan data di atas, menghasilkan angka Fhitung sebesar 58.748 dengan tingkat signifikansi sebesar 0,000. Setelah nilai Fhitung maka nilai Ftabel (sig=0.05) adalah 2.81. Karena nilai Fhitung lebih besar dibandingkan dengan Ftabel $(58.748>2.81)$ dengan tingkat siginifikan 0.000 $>0,5$ maka dapat disimpulkan H0 ditolak, berarti Brand Reputation dan Brand Experience berpengaruh positif dan signifikan terhadap Trust in a Brand.

Berdasarkan hasil pengolahan data di atas menghasilkan angka Thitung Brand Reputation 3.305 dan Brand Experience 3.526 dan Ttabel 1.678, maka hasilnya signifikan, karena hasil Thitung lebih besar dari Ttabel. Uji T berguna untuk menguji signifikansi koefisien regresi, yaitu apakah variable independen $(\mathrm{X})$ berpengaruh secara nyata. Berdasarkan hasil pengolahan data di atas menunjukkan angka B (beta) Brand Reputation sebesar 0.431 dan Brand Experiencesebesar 0.460.

Berdasarkan hasil output regresi linear berganda yaitu Brand Reputation, Trust in a Brand, dan Brand Experience, pada tabel summary dapat dikatakan koefisien (R) sebesar 0,979 menjelaskan bahwa variabel Brand Reputation, Trust in a Brand, dan Brand Experience berpengaruh terhadap Loyalitas Pelanggan sebesar 97,9\%. R square (R2) disebut koefisien determasi. Dari table dapat diketahui bahwa nilai R2 sebesar $0,958(95,8 \%)$ dan sig sebesar 0,000 . Artinya $95,8 \%$ variasi yang terjadi terhadap tinggi rendahnya Loyalitas Pelanggan disebabkan variasi Brand Reputation, Trust in a Brand, dan Brand Experience.

Berdasarkan hasil pengolahan data di atas menghasilkan angka Fhitung sebesar 354.064 dengan tingkat signifikansi sebesar 0,00. Setelah nilai Fhitung maka nilai Ftabel (sig=0.05) adalah 2.81. Karena nilai Fhitung lebih besar dibandingkan dengan Ftabel $(354.064>2.81)$ dengan tingkat siginifikan $0.00>0,5$ makadapat disimpulkan bahwa H0 ditolak, berarti Brand Reputation, Trust in a Brand, dan Brand Experience berpengaruh positif dan signifikan terhadap Loyalitas Pelanggan.

Berdasarkan hasil pengolahan data di atas menghasilkan angka Thitung Brand Reputation 3.8451, Trust in a Brand 3.451dan Brand Experience 12.852 dan Ttabel 1.678 maka hasilnya signifikan karena hasil Thitung lebih besar dari Ttabel. Uji T berguna untuk menguji signifikansi koefisien regresi, yaitu apakah variable independen $(\mathrm{X})$ berpengaruh secara nyata. Berdasarkan hasil pengolahan data di atas menunjukkan angka B (beta) Brand Reputation sebesar 0.213, Trust in a Brand sebesar 0.155, Brand Experience sebesar 0.679 .

Dari persamaan di atas menunjukkan bahwa: (1) Variabel Brand Reputation dan Brand Experience berpengaruh secara significant terhadap Trust in a Brand dengan nilai signifikansi Brand Reputation $0.002<0,005$ dan Brand Experience $0.001<0,005$, berarti H0 ditolak dan dinyatakan signifikan; (2) Variabel Brand Reputation, Trust in a Brand dan Brand Experience berpengaruh secara signifikan terhadap Loyalitas Pelanggan dengan nilai signifikansi Brand Reputation $0.000<0.005$ Trust in a Brand $0.001>0.005$ dan Brand Experience $0.000<0,005$ berarti H0 ditolak dan dinyatakan signifikan.

Hasil penelitian sebagai berikut:

H1: Diterima, karena Brand Reputation berpengaruh signifikan terhadap Trust in a Brand.

H2: Diterima, karena Brand Reputation berpengaruh signifikan terhadap Loyalitas Pelanggan.

H3: Diterima, karena Brand Experience berpengaruh signifikan terhadap Trust in a Brand.

H4: Diterima, karena Brand Experience berpengaruh signifikan terhadap Loyalitas Pelanggan.

H5: Diterima, karena Trust in a Brand berpengaruh signifikan terhadap Loyalitas Pelanggan.

\section{KESIMPULAN}

Iphone menjadi salah satu merek smartphone yang dipercaya mempunyai sepak terjang yang baik dalam dunia teknologi komunikasi. IPhone selalu dikaitkan dengan pemilik dengan penghasilan tinggi, dengan segmentasi pasar yang jelas yaitu kelas menengah keatas, menjadikan $i P h o n e$ tetap stabil dalam penggunaannya.

Berdasarkan hasil penelitian yang dilakukan dengan penyebaran kuesioner kepada 50 responden pengguna iPhone $X$, dapat diketahui bahwa terdapat pengaruh yang positif dan signifikan antara Brand Reputation terhadap Trust in a Brand dan Loyalitas Pelanggan. Brand Reputation merupakan opini orang lain bahwa merek tersebut dikenal luas dan mempunyai nama baik. Reputasi merek yang positif akan memengaruhi kepercayaan konsumen pada merek dan juga memutuskan untuk setia pada produk tersebut. 
Terdapat pengaruh yang positif dan signifikan antara Brand Experience terhadap Trust in a Brand dan Loyalitas Pelanggan. Brand Experience dapat dibentuk melalui suasana dan kesan produk yang baik, produk yang member pengalaman berbeda. Aspek tersebut menjadikan konsumen memiliki rasa kepercayaan dan kesetiaan pada produk. Terdapat pengaruh yang positif dan signifikan antara Trust in a Brand terhadap Loyalitas Pelanggan.

Loyalitas pelanggan dapat timbul dari rasa kepercayaan konsumen terhadap produk. Hasil penelitian ini menunjukkan bahwa pengaruh Brand Experience terhadap trust in brand dan loyalitas pelanggan lebih tinggi daripada Brand Reputation terhadap trust in a brand dan loyalitas pelanggan.

\section{DAFTAR PUSTAKA}

Brakus, J. J., Schmitt, B. H., \&Zarantonello, L. (2009). Brand Experience: What is It? How is it Measured? Does it Affect Loyalty? Journal of Marketing, 73(3), 52 https://doi.org/10.1509/jmkg.73.3.052

Creed, W. E. D., and Miles R. E. (1996). Trust in Organizations: A conceptual Framework Linking Organizatinal Forms, Managerial Philosophies, and the Opportunity Cost of Controls. In R. M. Kramer ang T. R. Tyler (eds.), Trust in Organizations: Frontiers of Theory and Research, Sage Publications, Inc

Fandy, T. (2008). StrategiPemasaran (3rd ed.). Jakarta: Andi Offset.

Gobe, Marc. (2003). Emotional Branding. Jakarta: Erlangga.

Harris, T. L. (1993). The Marketer's Guide to Public Relations: How Today's Top Companies are Using the New PR to Gain a Competitive Edge (Wiley Series on Business Strategy). Wiley.

HoetaSoehoet, A.M. (2002.) PengantarIlmuKomunikasi.Jakarta: Yayasan KampusTercinta IISIP.

Lau, G. T., \& Lee, S. H. (1999). Consumers' Trust in a Brand and the Link to Brand Loyalty. Journal of Market-Focused Management, 4(4), 341-370. https://doi.org/10.1023/a:1009886520142.

Ratih, H. (2010). Bauran pemasaran dan loyalitas konsumen. Jakarta: Alfabeta.

Gobe, M. (2003). Emotional Branding. Jakarta: Erlangga.

Koufaris, M., \& Hampton-Sosa, W. (2004). The development of initial trust in an online company by new customers. Information \& Management, 41(3), 377, https://doi.org/10.1016/j.im.2003.08.004

Kotler, Philip. (2000). ManajemenPemasaran. EdisiMilenium. Jakarta: Indeks Kelompok Gramedia

Kriyantono, R. (2008). Teknik PraktisRisetKomunikasi. Jakarta: Kencana Prenan Media Group.

Pertiwi, A. R., Djawahir, A. H., \&Andarwati, A. (2017). Pengaruh Brand Experience terhadap Brand Satisfaction, Brand Trust dan Brand Loyalty, Jurnal Manajemen dan Kewirausahaan, 5(2). https://doi.org/10.26905/jmdk.v5i2.1355

Silalahi, U. (2015). MetodePenelitianSosial. Jakarta: RefikaAditama

Simamora, B. (2001). Memenangkan Pasar dengan Pemasaran Efektifdan Profitable (1st ed.). Jakarta: GramediaPustaka Utama.

Sudarti, K., \& Putri, I. F. A. (2013). Peningkatan Loyalitas Pelanggan Melalui Reputasi Merek, Kepuasan Nasabah dan Kualitas Pelayanan untuk Mencapai Keunggulan Bersaing. Media Ekonomi dan Manajemen,

http://jurnal.untagsmg.ac.id/index.php/fe/article/view/202/265

Zarantonello, L., \& Schmitt, B. H. (2010). Using the brand experience scale to profile consumers and predict consumer behaviour. Journal of Brand Management, 17(7), 532-540. https://doi.org/10.1057/bm.2010.4 